\title{
Kollektiv erindring om al-Nakba
}

"Jeg elsker bestemoren min. Hun er alle palestineres bestemor, fordi hun er minnene om Palestina.” (Nimer (I6), Al-Azzeh flyktningleir, Betlehem). Korleis skal I948 erindrast i israelsk og palestinsk historie? For palestinarane var det ein katastrofe, for dei israelske jødane ein fridomskamp.

Av Hilde Lysengen Havro, cand.philol. i kulturhistorie frå UiO.

Denne artikkelen skal ta for seg nokre hovudmoment i palestinsk kollektivt minne, og syne korleis I948 fungerer som felles komponent for den palestinske identiteten.

Den israelske utdanningsministeren Yuli Tamir sette i fjor sumar i gang ein oppheita debatt etter at ho godkjende den arabiske utgåva av tekstboka "Å leve saman i Israel". ${ }^{.}$Dette er ei tekstbok for tredje klasse i grunnskulen, og blir gjeve ut i to utgåver; ei arabisk utgåve for den palestinske befolkninga i Israel, og ei hebraisk for den jødiske befolkninga. Det kontroversielle i arabiskutgåva er at teksten nemner at palestinarane vart forvist $\mathrm{i}$ I948, og at arabarane kallar krigen nakba, medan jødane kallar han frigjeringskrigen. Sjølv om den hebraiske teksten ikkje nemner den palestinske versjonen av I948, var Tamirs godkjenning som å stikke handa inn i eit vepsebol i eit land der palestinarane si historie medvite har vore utelaten frå historiebøkene i fleire tiår.

\section{Me hugsar kollektivt}

I Israel og Palestina er I948 ikkje berre eit årstal, det er eit kjensleladd omgrep som inneheld glede, sorg, sinne, frigjering og fordriving. I948 definerer byrjinga på både den israelske staten og den palestinske fordrivinga. Både den israelske og den palestinske nasjonsbygginga presenterer ei kollektiv erindring knytt til det same området for den same tidsperioden, men dette består $\mathrm{i}$ to ulike forteljingar som ofte tek utganspunkt i dei same historiske hendingane.

For både israelsk og palestinsk kollektiv erindring representerer I948 starten på noko nytt, men ei totalt ulik tilvere. Jødane gjekk frå det uvisse diasporatilveret til å få ein stat som kunne fungere som ei trygg ramme for det jødiske folket som nettopp hadde sett ein tredjedel av verdas jødar utrydda i Holocaust. Palestinarane gjekk frå å liggje under ei form for administrering og førestilling om ei mogleg statsdanning til det uvisse diasporatilveret som statslause. Reint diskursivt symboliserer også krigen i i948 dei to forteljingane: Jødane var vinnarane og har kalla krigen Frigjeringskrigen, palestinarane var taparane og kallar den same krigen for Katastrofen.

Sentralt i ein nasjonsdefinisjon er at nasjonen har ei sams kollektiv erindring. Nasjonalisme som politisk, sosialt og kulturelt program for nasjonen vil difor søkje å etablere eit kollektivt minne som kan fungere mellom anna som ein felles 
opphavsmyte for medlemene av nasjonen, og såleis etablere ein fellesskap mellom medlemene. ${ }^{2}$

I mellomkrigstida etablerte den franske sosiologen Maurice Halbwachs omgrepet kollektiv erindring som ein sosial konstruksjon der erindringa oppstår i ei gruppe (til dømes ein familie, ein hær, ei sosial klasse) ved at indvida, ved å vera medlemer av denne særskilte gruppa, brukar gruppa som ein kontekst for å minnast eller gjenskape fortida. ${ }^{3}$ Kvar gruppe har sitt distinkte minne, og det å hugse er ein grunnleggjande sosial aktivitet nødvendig for samhald og kommunikasjon. Identiteten til ei gruppe (eller ein nasjon) blir til i ein vekselverknad mellom identitet og erindring; identiteten blir vidareført gjennom erindring, og kva som blir erindra blir bestemt av identiteten. ${ }^{4}$ Som historikar John R. Gillis formulerer det: "Identities and memories are not things we think about, but things we think with". ${ }^{5}$ Identitet og erindring danner referansepunkt $\mathrm{i}$ vår oppfatning av korleis kvardagen vår er, forholdet vårt til andre menneske, ynske og draumar for framtida.

Uttrykk for den kollektive erindringa kjem til syne mellom anna i offisielle markeringar, i historiebøker, arkitektur, kulturlandsskap, minnesmerke og munnlege forteljingar som blir overførde frå generasjon til generasjon. I konfliktsamfunn vil det også eksistere ein konflikt om kva dette kollektive minnet skal innehalde og kven si historie som skal forteljast. Når ein stat eller hegemonisk nasjonsgruppe innanfor ein stat freistar å "stele" eit folks nasjonale identitet og medvit, blir det å gløyme, som motsetnad til å minnast, brukt som ein organisert metode. ${ }^{6}$ Majoriteten $i$ eit land kan ta hegemoni over fortida, og minori- tetane si historie blir ekskludert, til dømes gjennom historiebøker, nasjonale museum og minnedagar. Slik skjer det ei politisering av erindringa - når det ikkje er plass til "den andre" i ein stats kollektive erindring.

I offisiell israelsk erindring er høgtidsdagar knytte til jødisk historie. Dette gjer det sjølvsagt vanskelegare for dei israelske palestinarane å kjenne tilhøyrsle til staten, og samstundes kjenne ein aksept for deira historie. Særskilt gjeld dette minnedagane Yom Ha'Zikaron, som i Israel er minnedagen for jødiske falne i krig og terrorisme, og Yom Ha'Atsmaot, som er nasjonaldagen til minne om opprettinga av den israelske staten.

Palestinarane markerer Nakba-dagen I5. mai kvart år, som er datoen for opprettinga av Israel i følgje den gregorianske kalenderen. I år var det kanskje særskilt to hendingar som kan vera døme på korleis minnemarkeringar blir gjenstand for konflikt. I landsbyen Kafr Kanna i Galilea braut det ut konflikt mellom Islamic Movement ${ }^{7}$ og den statleg utnemnde landsbyoverhovudet då sistnemnde ikkje ynskte å gje organisasjonen løyve til å ha ei markering på 6oårsdagen for nakba på landsbyens stadion. Etter å ha samrådd seg med innanriksdepartementet kom den lokale ordføraren, Ilan Gavrieli, til at det ikkje var høve til å bruke eigedom tilhøyrande det lokale landsbyrådet til politiske markeringar. Islamic Movement gjekk rettens veg, fekk i distriktsretten i Nazaret medhald i at markeringa var lovleg, og landsbyrådet måtte tillate markeringa. ${ }^{8}$

Eit anna døme kan også syne kor viktig Nakba-dagen har vorte som minnedag for den palestinske befolkninga i Israel. Studentunionen ved Universitetet i Tel Aviv valde $\mathrm{i}$ vår å arrangere studentdagen for 
2008 den I5. mai. For dei palestinske studentane vart dette oppfatta som eit åtak på deira rett til å minnast Nakba-dagen, og den arabiske studentunionen arrangerte demonstrasjonar for å markere sitt syn. ${ }^{9}$ Den arabiske studentunionen hevda å ha gjort studentunionen merksame på samanfallet mellom den palestinske minnedagen og studentdagen, men at studentunionen valde å sjå vekk frå protestane frå palestinarane ved Universitetet.

\section{To typar erindring}

Ein kan skilje mellom to måtar å produsere ei oppfatning av fortida på; gjennom offentleg representasjon og gjennom privat erindring. ${ }^{\circ} \quad$ Palestinsk erindring som alternativ til israelsk historieskriving, har slik fungert som eit folkeleg opprør mot eit maktapparat. Det å erindre fungerer i denne situasjonen også som mot-historie og opprør mot den etablerte erindringa.

I vår oppfatning er fortida noko som har hendt, som ikkje kan endrast. Men samstundes blir fortida endra i samtida, for nettopp å kunne skapa ein kontinuitet mellom fortid og notid, og tilpasse henne notidas krav og ynske om nasjonal identitet og tilhøyrsle. II Identifikasjon med ei fortid og sams lagnad fungerer slik som eit grunnlag for fellesskapen. Med fordrivinga av det palestinske folket skjedde det også ei form for sameining av det palestinske folket, ein delte same lagnad som flyktningar og diaspora. ${ }^{\text {I2 }}$ Sjølv om majoriteten av den palestinske befolkninga vart fordrive frå landet, stogga ikkje utviklinga av ein nasjonal identitet opp, men innhaldet i minnet og identitetsutviklinga endra seg truleg i høve til slik det elles ville vore.

Opprettinga av Israel fungerer $i$ den israelske erindringa som ei re-etablering av den jødiske nasjonen i landet Israel, som er fødestaden for det jødiske folket. I den nasjonale forteljinga forsvann aldri lengsla etter heimlandet sjølv i den tida det jødiske folket var i eksil, og med opprettinga av Israel tok enno ein gong det jødiske folket sin plass mellom verdas nasjonar. ${ }^{13}$ For å skapa ein samanheng mellom fortid og notid freistar den sionistiske forteljinga å bruke konkrete historiske hendingar til å binde saman ei kollektiv erindring om desse hendingane til det geografiske området dei har skjedd. ${ }^{\text {I4 }}$ Slik oppnår ein også ei kulturell tilknyting til territoriet.

Nakba utgjer rotstrukturen i den palestinske forteljinga og erindringa. I palestinsk erindring har 1948 vorte eit slags nullpunkt i historia som definerer brotet mellom to heilt motsette periodar. Mange palestinske flyktningar refererer til heimlandet gjennom minnemarkeringar

\section{Palestinsk erindring, som alternativ til israelsk historieskriving, har}

fungert som eit folkeleg opprør.

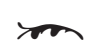

og minnehandlingar. Til dømes har dagen for massakren i landsbyen Deir Yassin, 9. april I948, vorte ein viktig minnedag for palestinarane for symbolsk å markere nakba. Fragmentering av befolkninga og tapet av eit heimland utvikla ein identitet basert på liding og urettvise, og på hendingar påført palestinarane via eksterne handlingar. ${ }^{15}$ Utvikling av ein heimlandsdiskurs og ein erindringsprosess som hugsar kva som gjekk tapt, er også ein viktig komponent. Nøkkelen har ei særskilt tyding for mange palestinarar, som symbol 
på at flyktningane låste døra til huset sitt i den tru at ein skulle vera borte berre nokre dagar. I dag blir nøkkelen i mange familiar overført frå generasjon til generasjon, og med den også ein draum om å kunne vende attende til heimstaden.

\section{Det palestinske kulturlandskapet blir borte} For ikkje-palestinske besøkande i Israel er det vanskeleg å tenkje seg at eit før-Israel bestod av hundretals palestinske landsbyar som ikkje lenger eksisterer. Som jordbrukssamfunn sette den palestinske befolkninga gjennom hundreåra sitt preg på landskapet dei kultiverte og gav namn til. Israelske styresmakter var difor tidleg ute med å re-definere det palestinske landskapet i den nye jødiske staten, av di dei arabiske landsbyane ikkje passa inn i den jødiske førestillinga om landskapet i heimlandet. ${ }^{16}$ Jødisk historie erstattar den arabiske kulturhistoria, og slik skjer det ein produksjon av fortid som har som funksjon å etablere ei sterkare tilknyting til området.

Landskapet vart hebraisert etter I948, forlatne arabiske landsbyar vart erstatta med nye byar, og namn på stader og landskapsformasjonar vart erstatta med nye, hebraiserte namn. Sjølv om tilknyting til historie var viktig, var det ikkje alltid bibelske namn som erstatta dei arabiske, i mange tilfelle vart det arabiske namnet skrive om slik at det klang hebraisk, men då utan ei særskilt tyding på hebraisk.

Sjølv om det innanfor ein stat er sterkt samband mellom ulike re-presentasjonar av historia og institusjonar som representerer makthierariket - som til dømes skulevesen, statsbyråkrati, kulturlandskapsvern - kan det også eksistere fleire og alternative re-presentasjonar av historia. ${ }^{17}$ Den politiske kampen om territoriet Stor-
Israel/Stor-Palestina er ikkje berre ein militær kamp om territorium, men også ein diskursiv kamp om korleis eit "rom" skal skildrast. Slik blir ein høgst politisk geografi konstruert $^{18}$ og også gjennom dette eit minne om ei kulturhistorie. Når eit særskilt samband mellom nasjon og landsskap er etablert har det samstundes skjedd ei stadleggjering av historia. ${ }^{19}$ Historia får meining ved at ho føregår i eit landsskap som er definert som nasjonalt. Samstundes får landsskapet særskilte nasjonale trekk gjennom historia som har skjedd i dette landsskapet.

Palestinarar i landflyktigheit byrja etter kvart å teikne ned kart over landsbyane sine, som i dag, i lag med den offisielle palestinske kartografien, kan fungere som svar på jødifiseringa av heimlandet. Desse karta vart inkluderte i minnebøker som palestinske flyktningar byrja å laga utover på I980-talet. ${ }^{\circ}$ Minnebøkene baserer seg hovudsakleg på historier fortalde av landsbybebuarar, inneheld detaljerte kart og detaljerte skildringar over landsbylivet, og fungerer som ei slags grasroterindring av heimlandet. Gjennom minnebøkene blir landsbyane sin eksistens synt fram og presentert i den (hugsa) forma landsbyen eksisterte i før nakba i I948, og dei historiske rettane blir oppretthaldne gjennom stadfesting av kunnskapen om landskapet. Gjennom desse minnebøkene blir heimlandet gjenskapa, og dei og fungerer som bevis på historisk eksistens.

\section{Landskap og nasjon i naturleg sameining}

I palestinsk nasjonal identitet blir småbrukaren symbolet på tilknytinga til landet. I I948 var fleirtalet av palestinarane knytte til primærnæringane, og då Artikkelen held fram på side 118 


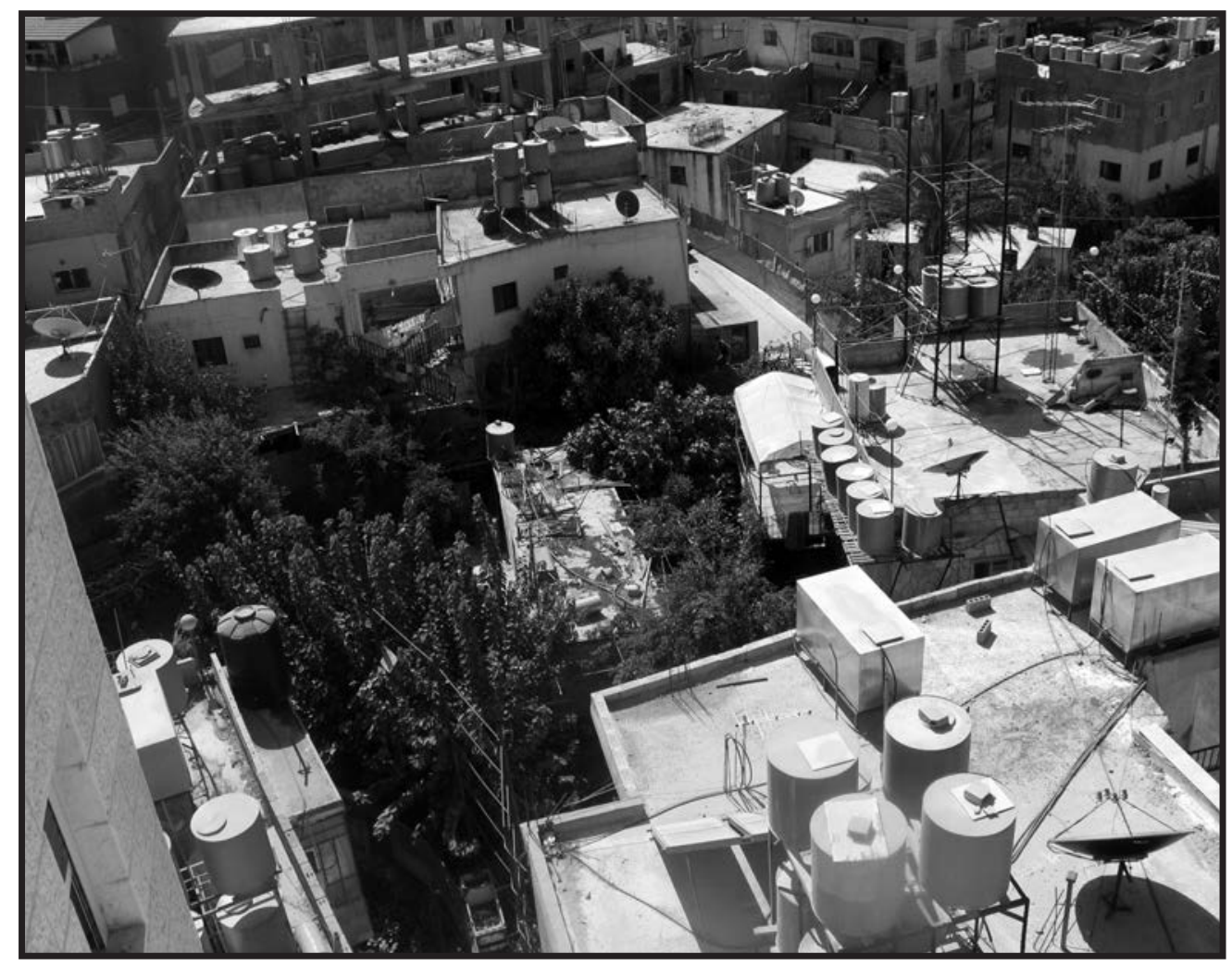

"We Palestinians are farmers; we need to grow something wherever it can be grown." Frå taket til Ibdaa Cultur Center i Deheisheh flyktningleir i Betlehem. 


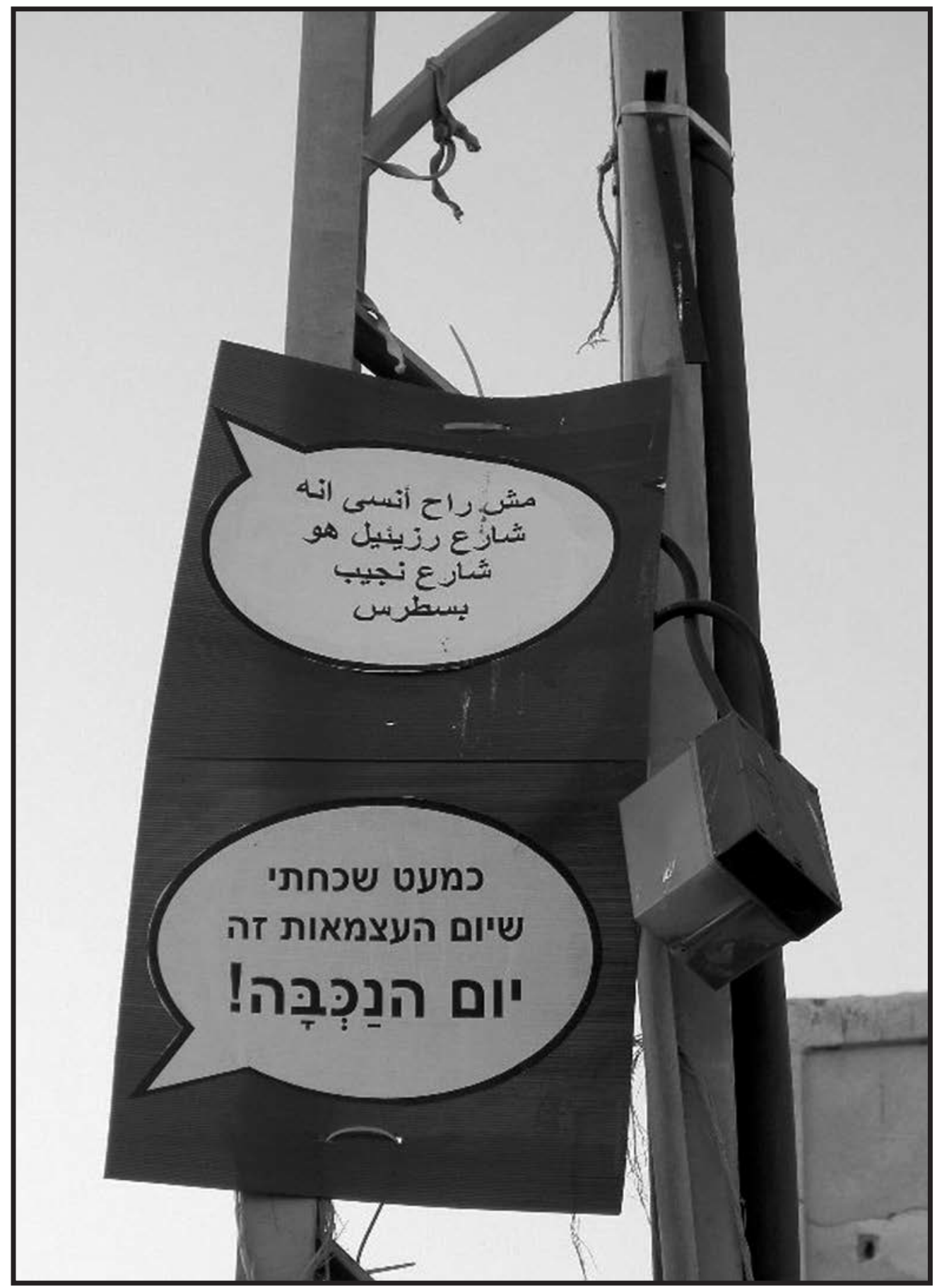

Teksten seier: "Eg gløymde nesten at Frigjeringsdagen er Nakba-dagen!” Plakat frå den israelske organisasjonen Zochrot (erindring) si markering våren 2006. 


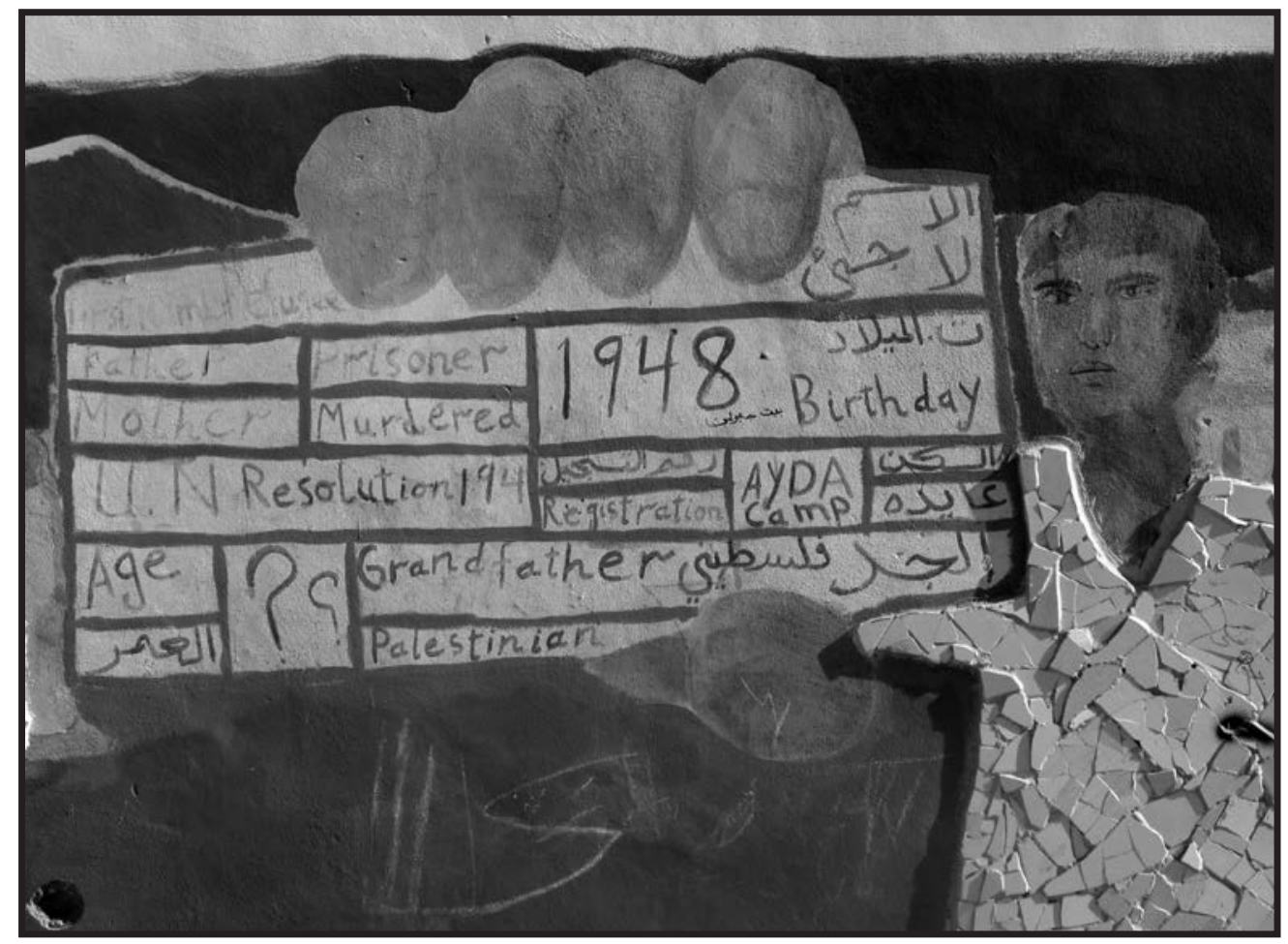

Palestinsk identitetskort, utsmykking utanfor Lajee-senteret i Aida flyktningleir i Betlehem. 


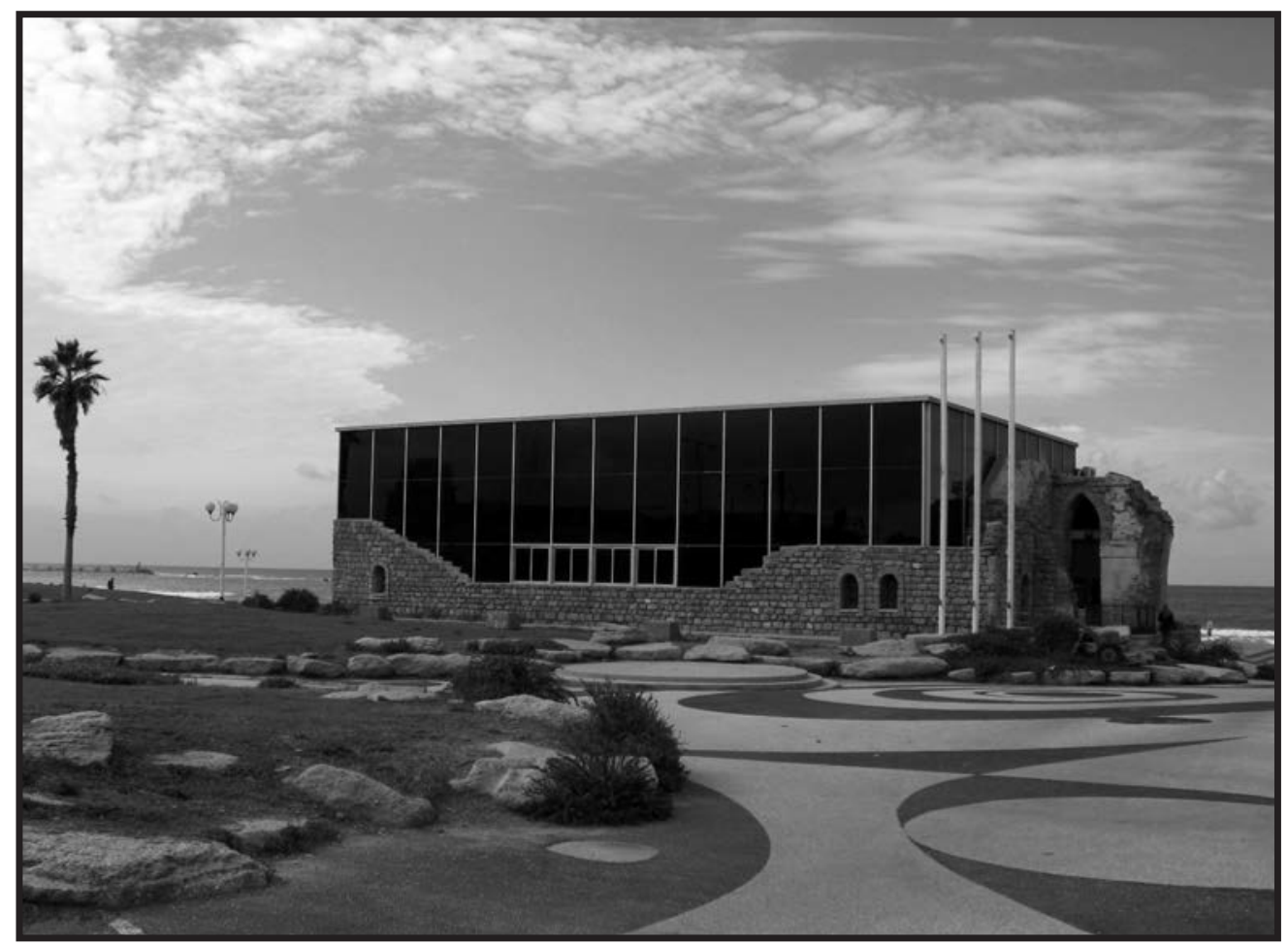

Museet for den militante undergrunnsorganisasjonen Irgun Zvai Leumi nord for Jaffa er bygd på ruinane av eit palestinsk hus. 


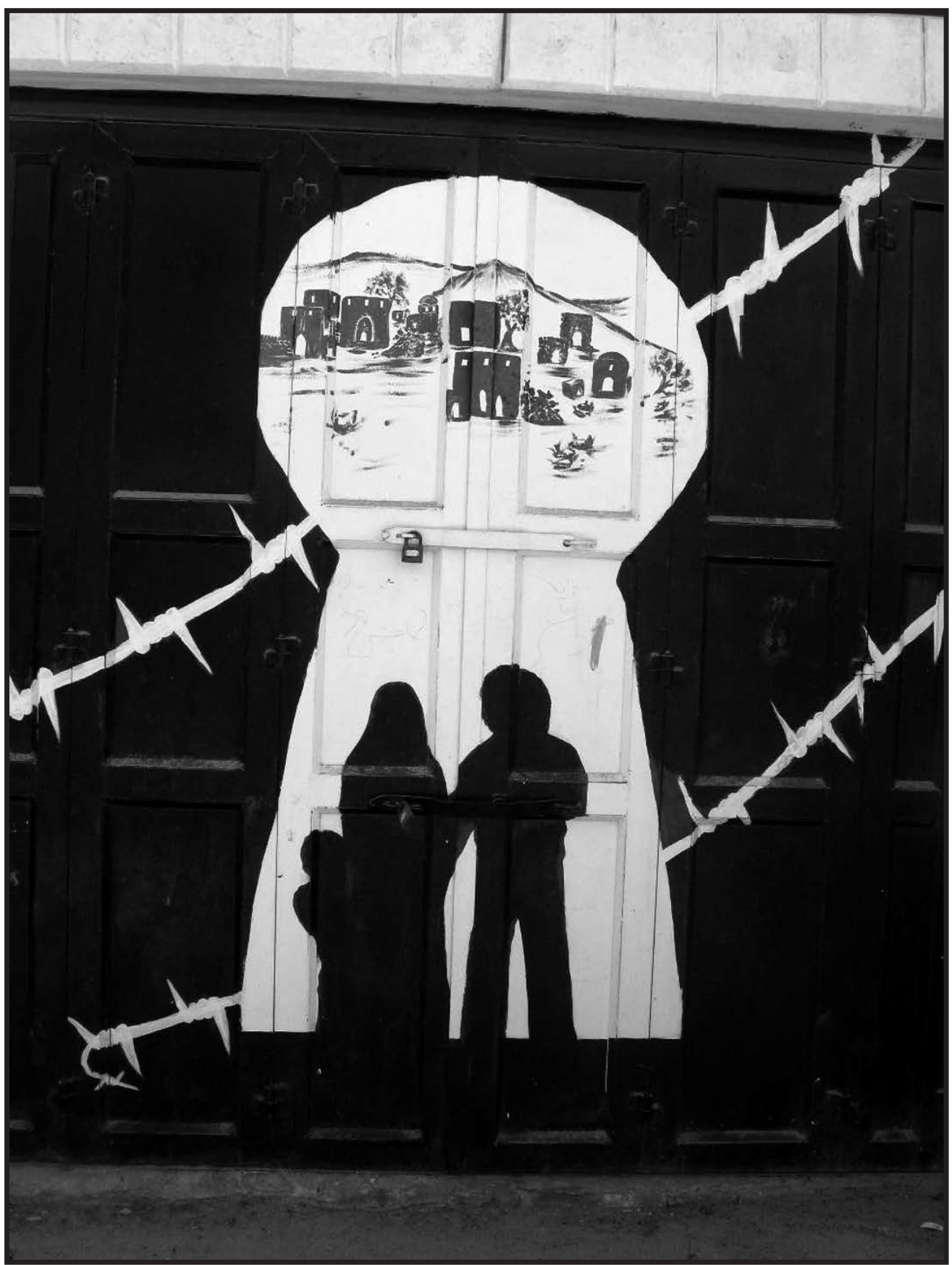

Utsmykking ved Lajee-senteret i Aida flyktningleir i Betlehem symboliserer tilhøyrsle, lengt og den forlatne palestinske landsbyen. 


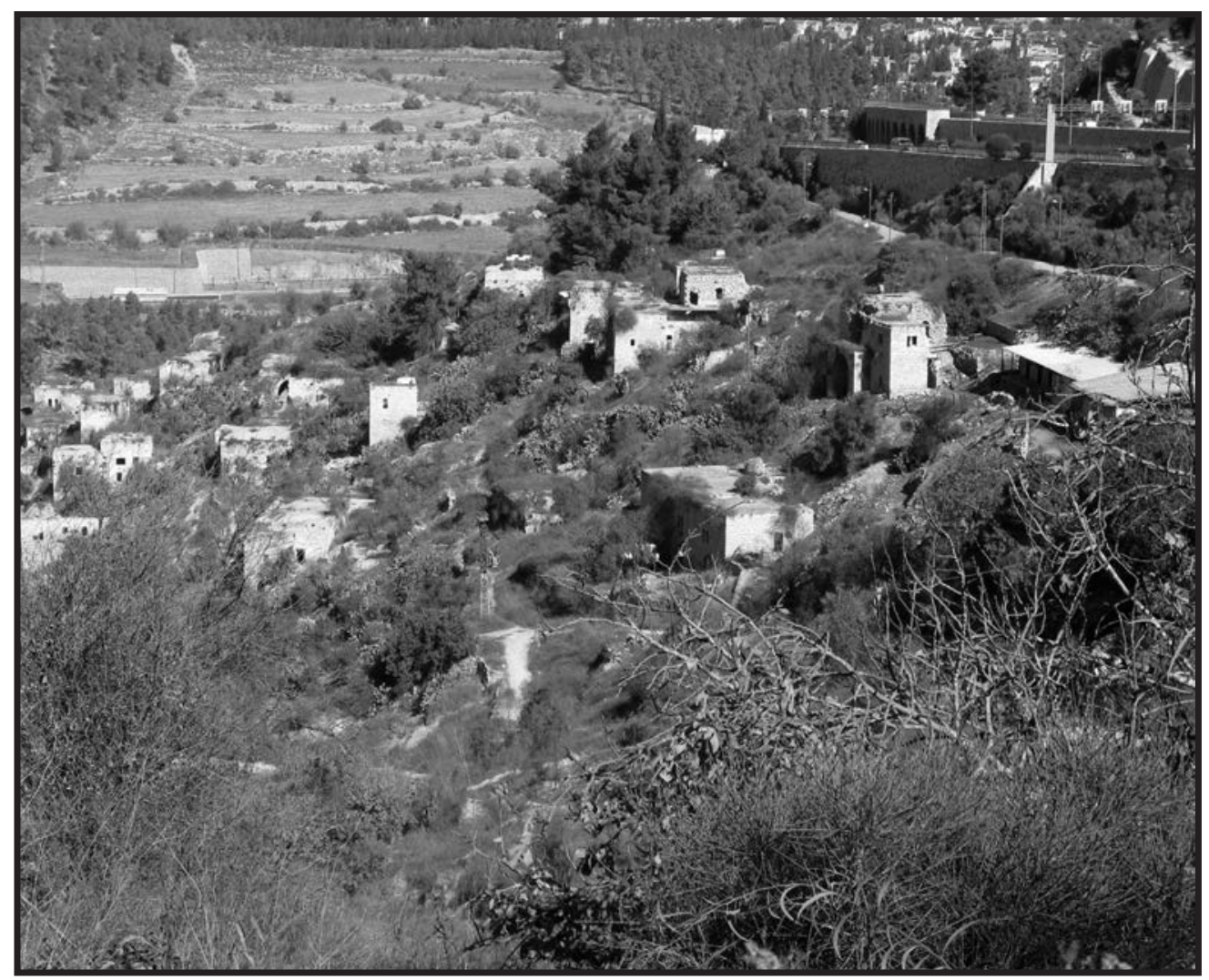

Lifta, vest for Jerusalem - ein av få palestinske landsbyar som ikkje vart øydelagt i åra etter I948. Eit framlegg om å gjera landsbyen om til eit museum har møtt protestar frå palestinarane, som fryktar at dette vil undergrave retten dei har til å vende attende. 
hovudsakleg landbruk. Småbrukaren, fellah, utgjer difor ikoniseringa av den palestinske fortida, eit slags "me var der og dyrka landet”, som ein motsetnad til dei sionistiske slagorda om "å få ørkenen til å bløme" og "eit land utan folk for eit folk utan land". Likevel er det ikkje det som var før nakba, men katastrofen i seg sjølv, som i erindringa tydeleggjer kva palestinarane har felles som folk: Gjennom å bli fordrive vart den palestinske identiteten forma. ${ }^{21}$

Som nemnd tidlegare blir nakba presentert som ei hending som utgjer eit brot i historia. Palestina blir hugsa før og etter dette brotet, og fokuset for minnet om heimlandet er landskap og forvaltning av dette. Den palestinske nasjonen blir framstilt som eit folk som har slått rot $\mathrm{i}$ jorda, og erindringa skal slik gje inntrykk av historiske rettar og krav: Palestinaren er like rotfesta i jorda som oliventreet, og høyrer naturleg til landet. Gjennom historiske hendingar og framstillingar blir nasjonen knytt til eit geografisk landsskap som framstår som uskiljeleg frå nasjonen. Å laga kart over landsbyane og landsskapet blir både ein måte å hugse og vidareføre kunnskap til dei neste generasjonane, og som eit bevis på at Palestina eksisterer.

\section{Erindring som prosjekt}

Historisk rekonstruksjon er ikkje avhengig av sosialt eller kollektivt minne, og er nødvendig sjølv om det i utstrekt grad eksisterer vitneskildringar av ei hending. Sosialt minne kan bli påverka av historisk rekonstruksjon, samstundes som det også kan fungere utfyllande i høve til skriftlege kjelder. Palestinske munnlege historie-prosjekt har ein slik funksjon. Ein situasjon i landflyktigheit og uavklara framtidig status er med på å oppretthalde den palestinske flyktningidentiteten der erindring og kunnskap blir overført frå ein generasjon til neste. Tradering skal gje ei kjensle av at ulike generasjonar opplever og erfarer det same, og i ein tilstand av å vera heimlaus kan det å vera palestinsk bli erfart som å vera på ei reise utan stopp, der den einaste haldeplassen er heimlandet. ${ }^{22}$

Flyktningane er forhindra frå å etablere ei tilknyting til landskapet gjennom direkte tilgang og bruk av det, ettersom dei palestinske flyktningane ikkje har lov til å returnere til sine opphavlege heimstader. I slike situasjonar må ein finne andre måtar å vidareføre tilknytinga til landskapet til neste generasjon. Dei seinare åra har det vorte starta fleire minneprosjekt, som til dømes det nettbaserte prosjektet Palestine Remembered, ${ }^{23}$ som mellom anna har samla inn personlege forteljingar, faktagrunnlag, bilete og kart og gjort dette tilgjengeleg for alle. Palestine Remembered starta i 2003 også eit eige nakba-prosjekt, der føremålet nettopp var å samle inn forteljingar frå fordrivinga i i948. Det Libanon-baserte Nakba-arkivet, ${ }^{24}$ etablert $\mathrm{i}$ 2002, legg også vekt på verdien av å samle inn og presentere personlege historier som del av dokumentasjonen av den palestinske historia før I948. Det eksisterer også planar om å etablere eit minnemuseum for Nakba, som i framtida kan bli hovudsenter for dokumentasjon av palestinsk før-I948historie. FNs organisasjon for dei palestinske flyktningane, UNRWA, forvaltar også flyktningane si historie. Denne våren laga UNRWA fotoutstillinga "I Come From There ... and Remember" for å minnast at det er 60 år sidan flyktningane vart fordrive. Utstillinga tok utgangspunkt $\mathrm{i}$ det rike fotoarkivet organisasjonen sit med, og målsetjinga med fotoutstillinga var å syne 
historie, folk og landskap i Palestina før I948. I Betlehem har det vore gjennomført fleire prosjekt der føremålet har vore å la nye generasjonar få kunnskap om historia gjennom at generasjonen som opplevde fordrivingane i I 948 og I9 67 fortel om sine opplevingar til unge palestinarar. Tredje og fjerde generasjons flyktningar får delta i eit sosialt kollektiv gjennom å ta del i kva som skjedde med foreldre og besteforeldre gjennom å intervjue eldre slektningar om deira personlege historier.

Lajee-senteret i Betlehem arrangerte i 2007 eit fotoprosjekt der ungdom knytte til senteret i Aida flyktningleir reiste til landsbyar familiane deira kom frå. Dette prosjektet enda i ei fotobok og fotoutstilling som har vore synt fram i Betlehem og andre stader. Undertittelen til eitt av bileta teke av ei ung jente er "My nightmare is to lose my home for the second time". Jenta har sjølv ikkje mista heimen sin tidlegare, ho er fødd i ein flyktningleir i Betlehem og har budd der heile livet. Men bestemora hennar kom som flyktning frå Beit Jibrin til Betlehem i i948, og for jenta var dette var fyrste gongen ho mista heimen.

\section{Å vera ein del av fortida}

Når palestinske flyktningar presenterer kvar dei kjem frå, svarar mange ofte landsbyen eller byen der familien opphavleg kom frå før I948. Sjølv familiar som har budd i flyktningleirar i snart 60 år, ynskjer ikkje nødvendigvis å definere flyktningleiren som heimstaden. For mange som har flykta eller busett seg i eit anna land (eller etterkomarar av norske Amerika-farande) er det for sjølvdefineringa likevel viktig å få fram kvar dei har røtene sine, sjølv om dei aldri har vore der. Det hugsa Palestina er eit glorifisert, romantisert drøyme-Palestina:
Det er der heime er, der fortida har skjedd, og der framtida skal skje.

For at nye generasjonar skal få ta del i tidlegare generasjonar si historie må det bli skapa ein samanheng mellom fortid og notid. Eit døme på dette er eit prosjekt ved Saint Joseph jenteskule i Betlehem som vart initiert i 2000. Prosjektet gjekk ut på at elevane ved skulen intervjua dei eldre generasjonane $\mathrm{i}$ familien om krigane $\mathrm{i}$ I948 og I967, og fleire av historiene vart trykt i "Your Stories are My Stories" våren 200I. ${ }^{25}$ Ei hovudmålsetjing for prosjektet, slik det er formulert i føreordet, er å ta vare på historia. Å dokumentere "det verkelege liv" gjennom nedteikning av personlege historier om kva som skjedde, sikrar at eldre generasjonars erfaringar, opplevingar og minne som det ikkje er plass til i historiebøkene, får leve vidare. ${ }^{26}$ Samstundes knytte prosjektet den yngre generasjonen tettare saman med den eldre generasjonen, og besteforeldras historier vart "[T]he students' own stories as part of an unbroken chain of Palestinian living and history." ${ }^{27}$

\section{"To be Palestinian is to suffer" 28}

Både palestinarane og israelarane framhevar si eiga lidingshistorie i den kollektive erindringa og kor unik deira lidingshistoria er. Offerrolle blir slik bunde saman med ein nasjonal identitet. I palestinsk kollektiv erindring blir lidinga til dei palestinske flyktningane eit viktig element i nasjonsbygginga, uttrykt $\mathrm{i}$ eit politisk krav om at verda må sjå lidinga til palestinarane og "gjera noko med det". Emile Saliyeh vektlegg nokre moment som grunnlaget for utvikling av ein palestinsk identitet ${ }^{29}$, som er knytte til minne om tap og smerte for palestinarane. Vanskelege sosiale og økonomiske forhold i flyktningleirane med 
utbreitt arbeidsløyse og generell mangel på utdanning og sosial- og helsetenester har gjeve grobotn for ei erindring om det palestinske folket som undertrykte og gløymde for all verda, og samstundes om "Palestina" som er det motsette av flyktningleiren. Også mangelen på implementering av FNs politikk andsynes flyktningane har ført til at palestinarane kjenner seg gløymd av det internasjonale storsamfunnet. Dei palestinske flyktningane sin rett til å vende attende til heimstadene sine vart vedteke av Generalforsamlinga II. desember I948, men Israel har trenert implementeringa av flyktingane sin returrett, og i dag er det lite truleg at resolusjonen vil bli gjennomførd når det gjeld flyktingane sin returrett. ${ }^{30}$ Erindring om massakrar som Deir Yassin i I948, Sabra og Shatilla i I982, borgarkrigen i Jordan i I970 og Libanon-krigen i I982, masseutvising frå Kuwait etter Gulfkrigen i I99I, og ein generell diskriminering $\mathrm{i}$ dei arabiske landa blir brukt som døme på at det palestinske folket generelt er i ein offersituasjon.

Jødisk historie er ei endelaus historie om antisemittisme, fordriving, diaspora, slavetid og undertrykking som kuliminerte i Holocaust under den andre verdskrigen. I israelsk erindring er Holocaust klimakset i ei 2000 år lang undertrykking av det jødiske folket, der den statens øvste målsetjing er å unngå at det jødiske folket hamnar i ein tilsvarande situasjon. Slik blir også I948 eit brot i den jødiske historia: Ein har berre seg sjølv å stole på, og nasjonalt sjølvstende blir slik knytt til militær sikkerheit for det jødiske folket.

Som motvekt til den israelske erindringa freistar nokre få frivillige organisasjonar å gje rom for den palestinske historia. Ein av desse er organisasjonen Zochrot, som på hebraisk tyder "erindring". Zochrot arbeider med å auke medvitet om den palestinske historia i Israel, og arrangerer jamlege turar til palestinske pre-I948 landsbyar. I tillegg arbeider organisasjonen for å reise skilt på stadene for dei palestinske landsbyane som i dag er erstatta med jødisk busetnader eller nasjonalparkar, som til dømes Canada-parken, som er etablert på ruinane til landsbyane Emaus, Yalu og Beit Nuba.

\section{Kvifor så vanskeleg for Israel?}

Det er heller vanleg at ein nasjon sitt offisielle kollektive minne er einsretta enn mangfaldig. Slik er det også i Noreg - det er liten plass for minoritetane si historie innanfor den norske forteljinga. Den nasjonale forteljinga føretrekkje ofte å fokusere på positive hendingar i historia, på storheitstid og heltedådar. Nakba representerer fordriving, massakrar, urettferdigheit, og legitimerer samstundes også eit anna folk si tilknyting til territoriet. Nakba bryt kort sagt med den sionistiske framstillinga om at jødane som det einaste folket har ei unik tilknyting til landet.

Likevel vil palestinarane halde fram med å søkje godkjenning for nakba. Er det då mogleg å sjå for seg at israelsk kollektivt minne på sikt kan inkludere nakba? Og korleis skal nakba i så fall erindrast mellom palestinarar? Nakba-erindringa i dag er hovudsakleg maskulint orientert, og vitnar også om ei einsretting innanfor den palestinske nasjonsbygginga. Det er til dømes lite fokus på kvinners historie og kvinners motstand, sjølv om det dei seinare åra også har vore større vektlegging på å få fram desse historiene. ${ }^{3 \mathrm{I}}$

Trass utdanningsminister Yuli Tamir sine spede freistnader på å inkludere nakbahistorie som pensum i den israelsk-arab- 
iske grunnskulen, er det lite som tyder på at den israelske offentlegheita er klar til å ta inn over seg katastrofen frå I948. Sjølv om forskinga til israelske historikarar (dei såkalla ny-historikarane) har opna for diskusjon om korleis fortida skal erindrast, reflekterer dei aller færraste jødiske israelarane over ruinar etter landsbyar eller hus som noko anna enn landskapets vakre innslag om ei gløymd tid.

\section{$\cdot f \cdot$}

I Stern, Yoav: "Education Ministry approves text referring to I948 as 'Nakba'". I Haaretz, Tel Aviv, 22. juli 2007.

2 Sjå mellom anna Smith, Anthony D.: "National Identity". Nevada: University of Nevada Press, I99I.

3 Halbwachs, Maurice: "Collective Memory". Chigaco: University of Chicago Press, I992.

4 Gillis, John R.: "Memory and Identity. The History of a Relationship" i Gillis, John R.: "Commemorations. The Politics of National Identity". New Jersey: Princeton University Press, I994, s. 3-24.

5 Gillis, John R. (I994) s. 5.

6 Connerton, Paul: "How Societies Remember". Cambridge: Cambridge University Press, I989.

7 Islamic Movement i Israel vart etablert i I983. Organisasjonen arbeider særskilt innanfor tre område: Promotere islam og sharia, tilby sosiale tenester og ta vare på islamsk kultur og vern om heilage stader. Islamic Movement vart splitta i ein sørleg og ein nordleg fraksjon i 1996 over spørsmålet om å anerkjenne den israelske staten. Den nordlege fraksjonen anerkjenner ikkje Israel.

8 Roffe-Ofir, Sharon: "Court permits Nakba rally". Ynet News, Tel Aviv, 5. mai 2008.

9 Zelikovich, Moran: "Arabs protest university's decision to hold Student Day on Nakba." Ynet News, Tel Aviv, I5. mai 2008.

Io Popular Memory Group: "Popular Memory: Theory, Politics, Methods" i Johnson, Richard (ed.): «Making Histories. Studies in Histroy-Writing and Politics» London: Hutchinson \&Co, 1982, s. 205-252

II David Lowenthal: «The Past is a Foreign Country». Cambridge: Cambridge University, 1985 .

I2 Sjå mellom anna: Sa'di, Ahmad H. og Lila Abu-Lughod (red.): "Nakba. Palestine, I948, and the Claims of Memory”. New York: Columbia University Press, 2007. Schultz, Helena Lindholm og Hammer, Juliane: «The Palestinian
Diaspora: Formation of Identities and Politics of Homeland» London: Routledge, 2003.

I3 Sjå Sjølvstendeerklæringa, mellom anna på heimesidene til det israelske utanriksdepartementet: mfa.gov.il

I4 Zerubavel, Yael: «Recovered Roots. Collective Memory and the Making of Israeli National Traditioon». Chicago, The University Press of Chicago, I995.

I5 Schultz, Helena Lindholm og Hammer, Juliane: «The Palestinian Diaspora: Formation of Identities and Politics of Homeland» London: Routledge, 2003.

I6 Benvinisti, Meron: «Sacred Landscape. The Buried History of the Holy Land since I948". Los Angeles: University of California Press, 2000.

I7 Popular Memory Group (I982) s. 207.

I8 Neumann, Iver B.: «Mening, materialitet, makt: En innføring i diskursanalyse» Bergen: Fagbokforlaget, 200I, s. 43.

I9 Anne Eriksen brukar omgrepet "stedliggjøring" i «Historie, minne, myte». Oslo, Pax Forlag, I999.

20 Davis, Rochelle: "Mapping the Past, Re-creating the Homeland. Memories of Village Places in pre-I948-Palestine" i Sa'di, Ahmad H. og Lila Abu-Lughod: «Nakba. Palestine, I948, and the Claims of Memory". New York: Columbia University Press, 2007, ss. 53-76.

2I Schultz og Hammer (2003), s. 97.

22 Schultz og Hammer (2003) s. 92.

23 Heimeside: palestineremembered.com.

24 Heimeside: nakba-archive.org

25 "Your stories are my stories" A Palestinian Oral History Project, Culture and Palestine series, Betlehem 200I

26 "Your stories are my stories" (200I) s. 8.

27 "Your Stories are my stories" (200I) s. 9.

28 Innlegg frå deltakar i kvinnegruppa til Arab Educational Institute, Betlehem. 2. januar 2008. Artikkelforfattaren var tilstade på møte.

29 Saliyeh, Emile: "The PLO and the Politics of Ethnonational Mobilization" i Sela, Avraham og Moshe Maoz: «The PLO and Israel. From Armed Conflict to Political Solution I964-I994». New York: St. Martin's Press,I997, S. 3-22

30 Resolusjonen A/RES/I94 (III), vedteke II. desember 1948 .

3I Sa'di, Ahmad H. og Lila Abu-Lughod (red.): «Nakba. Palestine, I948, and the Claims of Memory». New York: Columbia University Press, 2007. 